\title{
Locating disaster communication in changing communicative ecologies across the Pacific
}

\author{
Jessica Noske-Turner \\ RMIT University \\ Jo Tacchi \\ RMIT University \\ Heather Horst \\ RMIT University \\ Evangelia Papoutsaki \\ Unitec Institute of Technology
}

\begin{abstract}
:
The Pacific Island region is geographically and culturally diverse, with a significant range of communication infrastructures and challenges. Access and use of mobile phones has risen exponentially over the past five years. According to ITU statistics, around 6o percent of Pacific Islanders had access to a mobile in 2012, compared to just 10 percent in 2006. In many Pacific countries mobile phones are, therefore, emerging as a key element of the local communication systems, and are being be built into disaster management and communication plans. For these plans to be effective, however, we argue that access to, and affordability of, technologies represent only one dimension of what needs to be considered in effective disaster communication plans. They also need to consider appropriate technologies, local communicative ecologies, systems for the ownership and maintenance of infrastructures, and local knowledge and belief systems. With a focus on mobile and other telecommunications technologies, this paper provides an overview of disaster communication systems and infrastructures, practices and challenges in the region.
\end{abstract}

\section{Introduction}

Mobile phones are often the first electronic communication technology to be accessible to remote or previously unconnected populations, facilitating a 'multiplicity of relationships in areas that used to be relatively isolated' (Tenhunen 2008:516). Mobiles have become integrated into livelihood strategies and economic activity (Donner 2008; 2010; Jensen 2007; Wallis 2013), 'social logistics' (Tenhunen 2008) and the maintenance of relationships within and across national boundaries (Horst 2006). In times of natural and human-made disasters, they have also been viewed as holding potential for circulating and crowdsourcing information (Heinzelman \& Waters 2010; Roche et al 2013), providing status reports (Bengtsson et al 2011), 
moving money (Mas \& Moraczynski 2009) and documenting and 'witnessing' violence through videos and cameraphones (Reading 2009). Yet, the ways in which these technological affordances (often viewed as technological 'solutions') and the specifics of how this happens in particular places varies according to local social and cultural conditions as well as communication practices and cultural contexts. As some of the broader literature on mobile media and communication demonstrates, we need to pay attention to the different ways in which mobiles are appropriated and used in local contexts (Ling \& Horst 2011; Sey 2011; de Souza e Silva et al 2011; Wallis 2013). Mobiles can contribute to disaster communication and other social challenges, but they also need to be understood and utilised through local cultural and meaning systems (Horst \& Miller 2006; Horst \& Taylor 2014; Pertierra 2002; Wallis 2011).

In this paper we argue that local communicative ecologies need to be understood for the effective development of disaster communication plans and approaches. To make our case, we draw upon the findings from the Pacific Media Assistance Scheme (PACMAS)1 baseline study, a study of the state of media and communication across 14 countries in the Pacific region (Tacchi et al. 2013). The baseline was commissioned by ABC International Development and undertaken by a team of researchers from RMIT University (Australia), Unitec (New Zealand) and University of Goroka (Papua New Guinea) over ten months in 2012 and 2013. Data was collected according to a set of themes defined by PACMAS, through desk-based research, interviews with 212 'stakeholders' from across the region, and 25 interviews with members of a Panel of Expertise. We sent researchers to all 14 countries for between 2 and 7 days to conduct the stakeholder interviews. 'Stakeholder' interviews were conducted with the following groups of people:

- $\quad$ TVET (Technical and Vocational Education and Training) coordinators and providers

- Broadcast/communications technicians in government, telecommunications companies and broadcast (especially radio) organisations and media/communication technicians

- Government representatives involved in the planning and management of disasters and crises

- Media managers and professionals in state, private, community, mainstream media

- Communication for Development (C4D) \& ICT and development initiatives

- Climate change scientists, government ministers or representatives responsible for climate change

- $\quad$ NGO/CSOs that have climate change as part of their remit, NGO/CSOs that focus on youth and have climate change as part of their remit

- Health department officers/ministers; public health professionals/researchers

- National media association representatives 
The Panel of Expertise was made up of 28 people from across the region. Panel members were asked to complete a short questionnaire and verification document via email or phone. The verification document focused upon legislation and the media and communication environment in each country. This provided a mechanism for checking on whether data sourced through desk based research was up to date and accurate.

The Pacific region has a rich and complex media and communication environment. Radio, and in some areas television, are important platforms for communication across vast distances and audiences, while newer information and communication technologies have entered the media and communications landscape. Populations across the 14 countries included in the baseline study range from 1,538 to over 7 million. The demographic and geographic differences are extreme; for example Nauru is one island of 21 square kilometres, while Kiribati consists of 33 low-lying coral atoll islands, across 3.5million square kilometres of ocean. The fastest growing new technology in the region is the mobile phone. According to ITU statistics, in 2012 around 60 percent of Pacific Islanders had access to a mobile, compared to just 10 percent in 2006. Mobile phones are used in a variety of ways including voice communication and SMS (text), accessing the Internet and social media (Anderson 2013; Handman 2013; Lipset 2013; Watson 2011). In a number of Pacific countries (e.g. Fiji, Papua New Guinea, Samoa and Tonga), mobiles are increasingly being used for banking, payments and the circulation of transnational remittances (Horst 2013). Mobile phones are also 'converging' with other media by providing access to camera phones, video and Bluetooth functions that enable people to share and transfer images and other files between mobile phones. However, despite the growth in mobile phones and internet access, and the convergence of broadcast and ICTs in the region, barriers to the use of and participation in local and regional media and communication spaces still remain.

In the first section of this paper we describe the communicative ecologies approach. We then explore the range of disaster communication plans across the region. In the concluding section we illustrate the importance and relevance of a communicative ecology approach to unpack and inform responses to diverse communication environments in disaster communication planning.

\section{Communicative ecologies}

Mobile phone networks may be the first electronic communication infrastructure to reach many populations across the world, but they are not entering into a communication vacuum. Communicative ecologies refer to the complex systems of communication, media and information flows in a community, or the communicative assemblages (Slater 2013). Taking a 
communicative ecology approach means not assuming a hierarchy of ways of communicating, and being open to alternative ways of classifying communication and media platforms across different cultural locations. The approach prioritises local specificities of the ways in which information and communication flow between people and how this is understood. Here communication channels include not just electronic media channels but also through institutions (for example, kinship networks, various organisations and government departments), roads and buses, and any other communication channels, processes and practices that are significant in a particular context. Communicative ecologies are the everyday, complex networks of information and communication in individual and community lives. Our communication networks are complex and based on individual decisions and choices about how to use various media platforms, as well as broader issues of availability and access, and social and cultural barriers and opportunities. Understanding how information flows and how communication takes place is particularly important when it comes to understanding media and communication for development. All forms of communication and mediation are relevant to communicative ecologies, and this helps to ensure we consider and include new media infrastructures, platforms, devices and practices in our analysis, including broadband, social media and mobile phones as well as traditional and face to face communication protocols and practices.

For example, effective disaster planning and preparedness communication in Tuvalu requires an understanding of the cultural contexts, especially in relation to the local framing of climate change risks within Christian narratives. Although Tuvalu figures frequently in western news stories and documentaries in association with climate change, and despite the continual arrival of foreign journalists, the awareness of climate change and the increased risk of potentially devastating disasters among Tuvaluans is low and western information does not filter through to local people (Farbotko \& Lazrus 2011). This is especially true for people living on the outer islands. One participant from the NGO sector in Tuvalu interviewed for the baseline study stated:

You know, the world is more aware about Tuvalu and climate change than most people, like the local people here, you know... I mean, this sort of makes me worry too. (Tuvalu respondent number 9, see Tacchi et al. 2013).

Christian narratives, and especially the story of Noah's Ark, are deeply embedded in local public discourses on climate change and natural disasters, and influence the circulation of information in relation to increased risks associated with climate change (Paton \& Fairbairn-Dunlop 2010, 
see also Rika 2013), an observation echoed by many interviewees. The respondent quoted above explained the implications of the strong faith in divine protection from natural disasters among many Tuvaluans:

I think last two years a lot of awareness on climate change and the impact, [but] people still ignore and they, you know, the Bible when Noah's Ark, when God says, I'll give you a sign that there will be no more flood, and that is in the back of their mind today. They always refer to the Bible. (Tuvalu respondent number 9, see Tacchi et al 2013).

At other times, the information provided by the Churches complements awareness campaigns. Some churches are taking a proactive stance on this issue and play a leading role in climate change communication, which becomes particularly relevant in the context of the Christian narratives discussed above. Church representatives regularly visit communities on outer islands to present biblical and scientific information about climate change. One such person regularly writes a sermon in a monthly newsletter on climate change. More broadly, the Pacific Conference of Churches (PCC) has been working on advocacy and awareness programs on climate change through its network of church leaders, women and youth organisations (pacificconferenceofchurches.org). By contrast, the local mass media does not seem to have been a key part of climate change engagement so far.

Mobile phones enter existing communicative ecologies and, in the process, alter them. They are appropriated and made meaningful by local communities within their local context, grounded in the realities of the everyday lives of individuals and groups (Tacchi 2014; Tacchi, Kitner \& Crawford 2012) and depending on availability, affordability and a wide range of access issues. The legislative and regulatory infrastructures, cost, as well as geography are also important. By comparing these across the 14 countries $^{2}$ we can see that there are complex and diverse interrelationships between deregulation, policies, processes and practices. For example, Niue, which is unique among these countries for providing free public Wi-Fi, also has a lower mobile phone penetration rate. 
Table 1: Comparative media and communication environments in Melanesia

\begin{tabular}{|c|c|c|c|c|c|}
\hline Country & Television & Radio & Print & Telecoms & $\begin{array}{l}\text { Population and } \\
\text { geography }\end{array}$ \\
\hline Fiji & $\begin{array}{l}4 \text { commercial } \\
\text { companies } \\
\text { offering } 20 \\
\text { channels } \\
1 \text { church network }\end{array}$ & $\begin{array}{l}2 \text { government } \\
10 \text { commercial } \\
2 \text { church } \\
2 \text { community } \\
\text { (one campus) }\end{array}$ & $\begin{array}{l}12 \text { commercial } \\
3 \text { daily, } 4 \text { weekly, } \\
4 \text { monthly, } 1 \\
\text { quarterly } \\
1 \text { student } \\
2 \text { community }\end{array}$ & $\begin{array}{l}\text { Telecoms competitive } \\
\text { environment. } 84 \% \text { mobile } \\
\text { penetration, 28\% access the } \\
\text { internet (in 2011), rapidly } \\
\text { growing due to mobile phone } \\
\text { expansion }\end{array}$ & $\begin{array}{l}868,400 \text { pop } \\
332 \text { volcanic islands, } \\
\text { approximately } 110 \\
\text { inhabited, over } 18,274 \text { sq } \\
\text { km }\end{array}$ \\
\hline PNG & $\begin{array}{l}1 \text { commercial } \\
1 \text { public } \\
1 \text { commercial } \\
\text { (satellite) }\end{array}$ & $\begin{array}{l}3 \text { government } \\
7 \text { commercial } \\
2 \text { community } \\
5 \text { church }\end{array}$ & $\begin{array}{l}3 \text { commercial } \\
1 \text { church }\end{array}$ & $\begin{array}{l}\text { Telecoms competitive } \\
\text { environment. } 38 \% \text { mobile phone } \\
\text { penetration } \\
2 \% \text { access the internet }\end{array}$ & $\begin{array}{l}7,013,829 \\
462 \mathrm{sq} \mathrm{km} \text {, a group of } \\
\text { islands including the eastern } \\
\text { half of New Guinea island, } \\
\text { mountainous interior } \\
\text { (Highlands) }\end{array}$ \\
\hline $\begin{array}{l}\text { Solomon } \\
\text { Islands }\end{array}$ & $\begin{array}{l}2 \text { commercial } \\
1 \text { government } \\
\text { (international) } \\
1 \text { church } \\
\text { (international) }\end{array}$ & $\begin{array}{l}4 \text { government } \\
2 \text { commercial } \\
1 \text { church } \\
1 \text { community }\end{array}$ & 4 commercial & $\begin{array}{l}\text { Telecoms competitive } \\
\text { environment. } 50 \% \text { mobile phone } \\
\text { penetration, } 6 \% \text { access the } \\
\text { internet }\end{array}$ & $\begin{array}{l}538,000 \\
27,986 \mathrm{sq} \mathrm{km}, 992 \text { islands }\end{array}$ \\
\hline Vanuatu & $\begin{array}{l}1 \text { government } \\
2 \text { foreign } \\
\text { government } \\
2 \text { church } \\
\text { (international) }\end{array}$ & $\begin{array}{l}2 \text { government } \\
1 \text { commercial } \\
1 \text { community } \\
1 \text { church }\end{array}$ & 3 commercial & $\begin{array}{l}\text { Telecoms competitive } \\
\text { environment. } 76 \% \text { mobile phone } \\
\text { penetration, } 8 \% \text { internet access }\end{array}$ & $\begin{array}{l}245,600 \text { pop } \\
12,189 \text { sq km, } 83 \text { Islands ( } 65 \\
\text { inhabited) }\end{array}$ \\
\hline
\end{tabular}

Table 2: Comparative media and communication environments in Polynesia

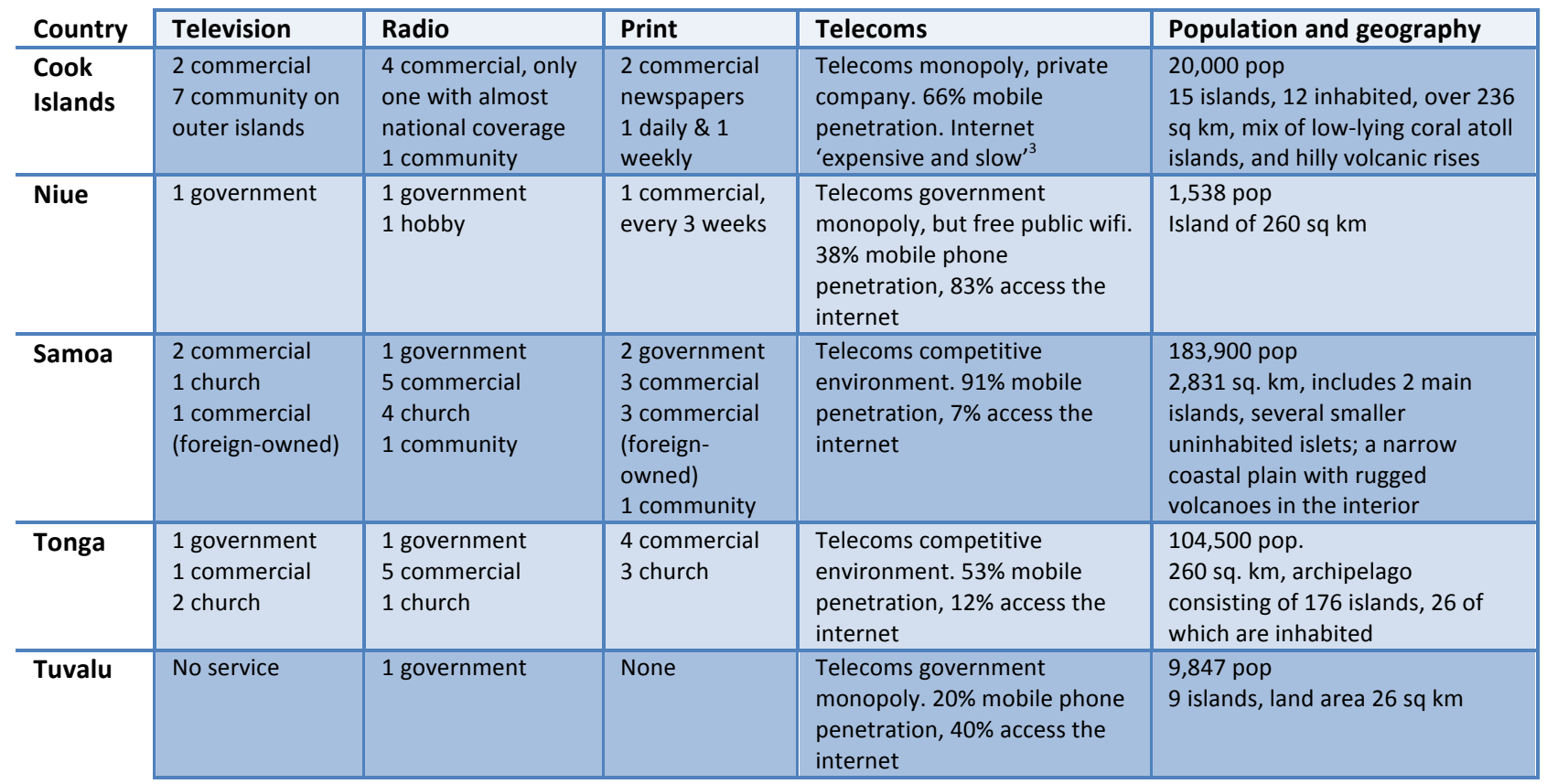


Table 3: Comparative media and communication environments in Micronesia

\begin{tabular}{|c|c|c|c|c|c|}
\hline Country & Television & Radio & Print & Telecoms & Population and geography \\
\hline FSM & $\begin{array}{l}4 \text { commercial } \\
\text { one in each } \\
\text { state }\end{array}$ & $\begin{array}{l}4 \text { government } \\
2 \text { commercial } \\
1 \text { church } \\
1 \text { community }\end{array}$ & $\begin{array}{l}1 \text { community } \\
\text { bi-weekly }\end{array}$ & $\begin{array}{l}\text { Telecoms monopoly, public } \\
\text { corporation. } 25 \% \text { mobile } \\
\text { penetration, } 20 \% \text { access the } \\
\text { internet }\end{array}$ & $\begin{array}{l}107,008 \text { pop } \\
607 \text { islands, combined land } \\
\text { area of } 702 \mathrm{sq} \mathrm{km} \text {, spread over } \\
2,600,000 \mathrm{sq} \mathrm{km} \text { of ocean, } \\
\text { made up of } 4 \text { federated states }\end{array}$ \\
\hline Kiribati & $\begin{array}{l}1 \text { government } \\
\text { currently not } \\
\text { operating }\end{array}$ & $\begin{array}{l}2 \text { government } \\
1 \text { commercial }\end{array}$ & $\begin{array}{l}1 \text { government } \\
2 \text { commercial } \\
1 \text { church } \\
\text { all weekly or less } \\
\text { frequent }\end{array}$ & $\begin{array}{l}\text { Telecoms monopoly, } \\
\text { government owned. } 14 \% \\
\text { mobile penetration, } 10 \% \\
\text { access the internet }\end{array}$ & $\begin{array}{l}103,000 \text { pop } \\
33 \text { low-lying coral atoll islands, } \\
21 \text { inhabited, land area of } 811 \\
\text { sq km, across 3,500,000 sq km } \\
\text { of ocean }\end{array}$ \\
\hline $\begin{array}{l}\text { Marshall } \\
\text { Islands }\end{array}$ & $\begin{array}{l}2 \text { commercial } \\
\text { with limited } \\
\text { coverage } \\
1 \text { US armed } \\
\text { forces }\end{array}$ & $\begin{array}{l}1 \text { government } \\
1 \text { commercial } \\
2 \text { church } \\
1 \text { US armed } \\
\text { forces }\end{array}$ & $\begin{array}{l}1 \text { commercial, } \\
\text { weekly }\end{array}$ & $\begin{array}{l}\text { Telecom monopoly, private } \\
\text { owned, government } \\
\text { controlled. } 7 \% \text { mobile } \\
\text { penetration, } 3.5 \% \text { access the } \\
\text { internet }\end{array}$ & $\begin{array}{l}54,800 \text { pop } \\
29 \text { coral atoll islands, } 24 \\
\text { inhabited, land area } 181 \mathrm{sq} \mathrm{km} \text {, } \\
\text { spread over } 1,210,000 \mathrm{sq} \mathrm{km} \text { of } \\
\text { ocean }\end{array}$ \\
\hline Nauru & 1 government & 1 government & $\begin{array}{l}1 \text { government, } \\
\text { monthly }\end{array}$ & $\begin{array}{l}\text { Telecoms competitive } \\
\text { environment. } 65 \% \text { mobile } \\
\text { penetration, } 6 \% \text { access the } \\
\text { internet }\end{array}$ & $\begin{array}{l}10,300 \text { pop } \\
21 \mathrm{sq} \mathrm{km} \text {, phosphate rock } \\
\text { island. }\end{array}$ \\
\hline Palau & $\begin{array}{l}1 \text { part } \\
\text { government } \\
\text { owned } \\
2 \text { commercial }\end{array}$ & $\begin{array}{l}1 \text { government } \\
3 \text { commercial } \\
2 \text { church }\end{array}$ & $\begin{array}{l}1 \text { government, } \\
\text { irregular } \\
3 \text { commercial, two } \\
\text { published irregularly } \\
\text { and one twice } \\
\text { weekly }\end{array}$ & $\begin{array}{l}\text { Telecoms near government } \\
\text { monopoly. } 80 \% \text { mobile phone } \\
\text { penetration, } 6 \% \text { access the } \\
\text { internet }\end{array}$ & $\begin{array}{l}26,610 \text { pop } \\
>300 \text { islands, } 8 \text { inhabited. } \\
\text { Mountainous and low, coral } \\
\text { islands. land area } 458 \mathrm{sq} \mathrm{km}\end{array}$ \\
\hline
\end{tabular}

As the media and communication environment becomes more complex, questions remain about the appropriateness of ICTs for specific purposes, such as disaster communication. For example, there is uncertainty in some places about the ability of broadcasters and technicians to keep upto-date with the latest equipment and software and the consequences of integrating ICTs like mobile phones into communication plans, compared with 'tried and tested' technologies such as broadcast radio. Studies of media in the Pacific - especially in large countries such as Papua New Guinea - from only five years ago considered access to new digital infrastructure less relevant than access to traditional media, especially radio (Duffield, Watson and Hayes 2008). More recent studies find ICTs are becoming more relevant, and indeed are under-utilised for development despite presenting significant potential (Cave 2012). In places such as PNG, where radio has been a dominant and effective platform, recent studies suggest that more households now have access to mobiles than to radio (Intermedia Europe 2012). In fact, our research, and the research of others, suggests that people are increasingly using their mobile devices to access radio programmes (Cave 2012). Intermedia Europe found that in PNG, mobiles are amongst the most common ways to access the Internet, with Facebook one of the most accessed sites (Intermedia Europe 2012). 
Communicative ecologies, and the place of mobile phones within these, may differ from person to person and across generations too. For example, Marion Muliaumaseali'i, a PhD researcher in Samoa, used the communicative ecologies approach to reflect on the generational difference in seeking information, and the perceived trustworthiness of different information sources (Muliaumaseali'i 2014). She describes how she heard about a tsunami warning on Facebook from a friend who worked for the Samoan government. She 'googled' the earthquake and found that a tsunami watch warning had been issued. She then gained more information from her taxi driver who felt the quake and was listening to the state radio station, 2AP, as it was broadcasting about the warning in Samoan. She contrasts this with her grandmother and aunt's preferred communication platforms. The aunt, in her late 50s, and the grandmother, in her 90s, 'would only believe that the warning was cancelled once it was announced on the radio', even though this information was already available online.

Despite the growth in mobile phones and internet access, and the convergence of broadcast and ICTs, barriers to the use of and participation in local, national and transnational media persists. In the baseline research we found that the internet in Tuvalu (provided by the government) was often down for days at a time and, when available, had serious connection problems. The quality and availability of mobile phone signals varies across the countries, and within countries, so that in some places people have to walk to 'bush phone booths', a term to describe a location where there is reception (Intermedia Europe 2012). The geography of media access impacts on the diversity of media sources in specific locations in the Pacific. In PNG levels of accessibility are mainly associated with geography rather than demographics such as age, gender and education (Intermedia Europe 2012). Geographic regions can be described in terms of whether they are 'media-rich' or 'media dark' (Intermedia Europe 2012). In PNG, media dark areas are predominantly located in the islands. TV and newspapers are mainly accessed in urban areas, so that radio and word of mouth remain a significant source of information, especially via family members and friends who travel between provinces in PNG. This situation of differential access is repeated in different ways in other Pacific countries, such as Tuvalu, Marshall Islands, Palau, Kiribati where isolation means that outer islands receive only government radio, or sometimes no mass media at all. Face-to-face communication remains highly valued across all Pacific countries. 


\section{Comparison of Disaster Communication Plans and Systems}

A range of media and communication platforms are now being used to provide access to early warning systems before a disaster. Tables 4, 5 and 6 below compare the existence of policies and plans in each country (arranged by region), and the types of communication platforms used.

Table 4: Role of media in disaster response and preparedness in Melanesia

\begin{tabular}{|c|c|c|c|c|c|}
\hline Country & Relevant legislation & $\begin{array}{l}\text { Main institutions \& } \\
\text { organisations }\end{array}$ & $\begin{array}{l}\text { Role of broadcast } \\
\text { media }\end{array}$ & Role of telecom & $\begin{array}{l}\text { Primary media } \\
\text { platforms used }\end{array}$ \\
\hline Fiji & $\begin{array}{l}\text { Disaster Management } \\
\text { Act (1998), National } \\
\text { Disaster Management } \\
\text { plan (1995), municipal } \\
\text { disaster management } \\
\text { plans. }\end{array}$ & $\begin{array}{l}\text { National Disaster } \\
\text { Management Council } \\
\text { (DISMAC), Red Cross, } \\
\text { Public Works } \\
\text { Department (PWD), } \\
\text { Ministry of Health, } \\
\text { Ministry of Agriculture, } \\
\text { the Military, the Police, } \\
\text { Fiji Meteorology } \\
\text { Service. }\end{array}$ & $\begin{array}{l}\text { Government } \\
\text { broadcasters (Radio Fiji } \\
\text { and FM96) are formally } \\
\text { integrated into National } \\
\text { Disaster Plans. }\end{array}$ & $\begin{array}{l}\text { Formal agreements } \\
\text { in place for the } \\
\text { provision of free } \\
\text { emergency calls } \\
\text { (Telecom Fiji, } \\
\text { Vodafone \& Digicel), } \\
\text { and use of networks } \\
\text { during disasters } \\
\text { (Telecom Fiji \& } \\
\text { Digicel). }\end{array}$ & $\begin{array}{l}\text { Radio Fiji \& FM96 } \\
\text { sirens (in Suva) } \\
\text { official websites } \\
\text { email } \\
\text { TV } \\
\text { social network sites } \\
\text { SMS messages } \\
\text { (Vodafone) }\end{array}$ \\
\hline PNG & $\begin{array}{l}\text { Disaster Management } \\
\text { Act currently being } \\
\text { reviewed. PNG Vision } \\
\text { 2050, National Disaster } \\
\text { Management Plan, } \\
\text { National Disaster } \\
\text { Mitigation Policy and } \\
\text { Disaster Risk Reduction, } \\
\text { and Disaster } \\
\text { Management National } \\
\text { Framework for Action } \\
2005-2015 .\end{array}$ & $\begin{array}{l}\text { National Disaster } \\
\text { Centre, provincial } \\
\text { disaster offices, } \\
\text { military, National } \\
\text { Weather Office, Geo } \\
\text { Physical Observatory }\end{array}$ & $\begin{array}{l}\text { Formal disaster plans } \\
\text { involve the National } \\
\text { Broadcasting } \\
\text { Corporation (including } \\
\text { its } 19 \text { provincial } \\
\text { stations) to disseminate } \\
\text { information. }\end{array}$ & $\begin{array}{l}\text { Telecoms are } \\
\text { formally integrated } \\
\text { into disaster plans, } \\
\text { however most } \\
\text { disaster initiatives } \\
\text { are based on } \\
\text { informal } \\
\text { agreements. }\end{array}$ & $\begin{array}{l}\text { NBC Radio (including } \\
\text { provincial stations), } \\
\text { some use internet and } \\
\text { mobile } \\
\text { communications. HF } \\
\text { radio (for emergency } \\
\text { services). }\end{array}$ \\
\hline $\begin{array}{l}\text { Solomon } \\
\text { Islands }\end{array}$ & $\begin{array}{l}\text { National Disaster Risk } \\
\text { Management Plan } 2010 \\
\text { for Disaster } \\
\text { Management } \\
\text { Arrangements and } \\
\text { Disaster and Climate } \\
\text { change Risk Reduction, } \\
\text { (national plan in } \\
\text { progress) }\end{array}$ & $\begin{array}{l}\text { National Disaster } \\
\text { Management Office, } \\
\text { National Disaster } \\
\text { Councils (national and } \\
\text { provincial), Police, Red } \\
\text { Cross, NGOs and civil } \\
\text { society, private sector, } \\
\text { Ministry for Energy and } \\
\text { Mines, Meteorology } \\
\text { Service. }\end{array}$ & $\begin{array}{l}\text { In the National Disaster } \\
\text { Risk Management Plan } \\
\text { Broadcasters are } \\
\text { considered 'Critical } \\
\text { Infrastructure Agencies' } \\
\text { and are therefore } \\
\text { formally required to } \\
\text { work within the plan. In } \\
\text { the event of an } \\
\text { emergency, SIBC hands } \\
\text { control over to the } \\
\text { NDMO. }\end{array}$ & $\begin{array}{l}\text { Telekom is included } \\
\text { in the national } \\
\text { Disaster Risk } \\
\text { Management Plan. } \\
\text { NDMO may seek } \\
\text { assistance from } \\
\text { Telikom in } \\
\text { emergencies. }\end{array}$ & $\begin{array}{l}\text { Radio (SIBC), church } \\
\text { bells or conch shells. } \\
\text { HF Radio and email } \\
\text { among disaster } \\
\text { responders. Telekom is } \\
\text { exploring opportunities } \\
\text { for warnings via mobile } \\
\text { phones. }\end{array}$ \\
\hline Vanuatu & $\begin{array}{l}\text { Disaster Risk Reduction } \\
\text { (DDR) and Disaster } \\
\text { Management (DM) } \\
\text { National Action Plan } \\
\text { (2006-2016) }\end{array}$ & $\begin{array}{l}\text { Vanuatu Meteorology } \\
\text { and Geo-Hazards } \\
\text { Department (VMGD), } \\
\text { National Advisory } \\
\text { Board (NAB) on Climate } \\
\text { Change and Disaster } \\
\text { Risk Reduction, } \\
\text { National Disaster } \\
\text { Management Office } \\
\text { (NDMO) }\end{array}$ & $\begin{array}{l}\text { Formal agreement } \\
\text { (MOU) signed between } \\
\text { VBTC the NDMO \& } \\
\text { VMGD outlining } \\
\text { procedures for } \\
\text { broadcasting of official } \\
\text { emergency information. } \\
\text { NDMO send emergency } \\
\text { information updates to } \\
\text { all radio stations, } \\
\text { including VBTC. }\end{array}$ & $\begin{array}{l}\text { Informal } \\
\text { agreements are } \\
\text { being developed } \\
\text { between } \\
\text { Meteorology and } \\
\text { Digicel (among } \\
\text { others). Telecom } \\
\text { providers have } \\
\text { internal plans. }\end{array}$ & $\begin{array}{l}\text { Radio (VTBC), warning } \\
\text { lights at Police } \\
\text { Headquarters, satellite } \\
\text { phones (in each } \\
\text { village). Currently no } \\
\text { agreement on using } \\
\text { mass-SMS messages or } \\
\text { other ICTs. }\end{array}$ \\
\hline
\end{tabular}


Table 5: Role of media in disaster response and preparedness in Polynesia

\begin{tabular}{|c|c|c|c|c|c|}
\hline Country & $\begin{array}{l}\text { Relevant } \\
\text { legislation }\end{array}$ & $\begin{array}{l}\text { Main institutions } \\
\text { \& organisations }\end{array}$ & $\begin{array}{l}\text { Role of broadcast } \\
\text { media }\end{array}$ & Role of telecom & $\begin{array}{l}\text { Primary media } \\
\text { platforms used }\end{array}$ \\
\hline $\begin{array}{l}\text { Cook } \\
\text { Islands }\end{array}$ & $\begin{array}{l}\text { National Disaster } \\
\text { Management Act } \\
\text { drafted in } 2007 \text { but } \\
\text { not passed. }\end{array}$ & $\begin{array}{l}\text { Emergency } \\
\text { Management Agency, } \\
\text { Police Commissioner, } \\
\text { Media Office, } \\
\text { Minister of Works, } \\
\text { Red Cross }\end{array}$ & $\begin{array}{l}\text { Currently no formal } \\
\text { arrangement for } \\
\text { emergency } \\
\text { broadcasting; plan is } \\
\text { reportedly in progress. }\end{array}$ & $\begin{array}{l}\text { Currently no formal } \\
\text { arrangement with } \\
\text { Telecom for service } \\
\text { provision during a } \\
\text { disaster }\end{array}$ & $\begin{array}{l}\text { Radio (especially } \\
\text { Radio Cook Islands) } \\
\text { Sirens (on Rarotonga } \\
\text { only) } \\
\text { HF radios } \\
\text { Satellite phones } \\
\text { Telecom has an } \\
\text { emergency plan. } \\
\text { Some capacity to } \\
\text { send SMS messages. }\end{array}$ \\
\hline Niue & $\begin{array}{l}\text { National Disaster } \\
\text { Plan (2010), Public } \\
\text { Emergency } \\
\text { Regulation (2004) }\end{array}$ & $\begin{array}{l}\text { National Disaster } \\
\text { Council, Chief of } \\
\text { Police, Niue } \\
\text { Meteorology Service }\end{array}$ & $\begin{array}{l}\text { The government radio } \\
\text { (BCN Radio) is formally } \\
\text { integrated into the } \\
\text { National Disaster Plan. }\end{array}$ & $\begin{array}{l}\text { Niue Telecom is } \\
\text { formally integrated } \\
\text { into the National } \\
\text { Disaster Plan. }\end{array}$ & $\begin{array}{l}\text { Radio Sunshine } \\
\text { (BCN), police cars } \\
\text { travel to villages. } \\
\text { Plans for sirens. Niue } \\
\text { Telecom is exploring } \\
\text { options for mass } \\
\text { messages via mobile } \\
\text { phones. Response } \\
\text { stakeholders use } \\
\text { email, phones, paper } \\
\text { notes and HF radio } \\
\text { communication }\end{array}$ \\
\hline Samoa & $\begin{array}{l}\text { National Disaster } \\
\text { Management Act } \\
\text { 2007, National } \\
\text { Disaster } \\
\text { Management Plan } \\
(2011-2016)\end{array}$ & $\begin{array}{l}\text { Disaster Monitoring } \\
\text { Office, Disaster } \\
\text { Advisory Committee, } \\
\text { Police, Samoa } \\
\text { Meteorology Division, } \\
\text { Ministry of Natural } \\
\text { Resources and } \\
\text { Environment }\end{array}$ & $\begin{array}{l}\text { Media organisations } \\
\text { are included in the } \\
\text { National Disaster Plan, } \\
\text { and formal plans } \\
\text { describe the } \\
\text { government AM radio } \\
\text { station, 2AP, as the } \\
\text { primary media outlet in } \\
\text { emergencies. }\end{array}$ & $\begin{array}{l}\text { The National } \\
\text { Emergency } \\
\text { Telecommunications } \\
\text { Plan involves Digicel } \\
\text { and BlueSky Samoa. }\end{array}$ & $\begin{array}{l}\text { 2AP (government AM } \\
\text { radio broadcaster), } \\
\text { network of sirens } \\
\text { and bells. Digicel can } \\
\text { send mass-SMS } \\
\text { messages }\end{array}$ \\
\hline Tonga & $\begin{array}{l}\text { Emergency } \\
\text { Management Act } \\
\text { 2007, National } \\
\text { Emergency } \\
\text { Management Plan } \\
\text { 2007, draft Tsunami } \\
\text { Plan }\end{array}$ & $\begin{array}{l}\text { National Emergency } \\
\text { Management } \\
\text { Committee, National } \\
\text { Emergency } \\
\text { Management Office, } \\
\text { Tonga Meteorological } \\
\text { Service, Regional } \\
\text { Meteorological Office } \\
\text { in Fiji }\end{array}$ & $\begin{array}{l}\text { National Emergency } \\
\text { Management Plan } \\
\text { (2007) outlines the } \\
\text { roles of the Tonga } \\
\text { Broadcasting } \\
\text { Corporation (TBC). TBC } \\
\text { is expected to continue } \\
\text { live broadcasts } \\
\text { throughout impact. } \\
\text { Work on the TBC } \\
\text { Emergency } \\
\text { Management Plan is in } \\
\text { progress }\end{array}$ & $\begin{array}{l}\text { National Emergency } \\
\text { Management Plan } \\
\text { (2007) outlines the } \\
\text { roles of the Tonga } \\
\text { Telecommunications } \\
\text { Corporation (TTC). } \\
\text { Responsible for } \\
\text { maintenance of } \\
\text { telecommunication } \\
\text { capacity, reporting to } \\
\text { Government on } \\
\text { capacity status. }\end{array}$ & $\begin{array}{l}\text { Radio Tonga (TBC), } \\
\text { commercial media } \\
\text { outlets, mobile } \\
\text { phones (for calling). } \\
\text { Warning sirens being } \\
\text { piloted. Digicel uses } \\
\text { a bulk SMS system. }\end{array}$ \\
\hline Tuvalu & $\begin{array}{l}\text { National Disaster } \\
\text { Plan (1997, revised } \\
\text { 2011), Disaster } \\
\text { Management Act } \\
\text { (revised 2007) }\end{array}$ & $\begin{array}{l}\text { National Disaster } \\
\text { Management } \\
\text { Committee, Disaster } \\
\text { Task Force, Tuvalu } \\
\text { Meteorology Service }\end{array}$ & $\begin{array}{l}\text { No official emergency } \\
\text { broadcasting plan. } \\
\text { Disaster Task Force } \\
\text { responsible for } \\
\text { information } \\
\text { dissemination via Radio } \\
\text { Tuvalu }\end{array}$ & $\begin{array}{l}\text { ICTs are not } \\
\text { integrated into } \\
\text { national plans. } \\
\text { Telecom provider has } \\
\text { internal plans. }\end{array}$ & $\begin{array}{l}\text { Radio (Tuvalu Radio), } \\
\text { police cars with } \\
\text { sirens and } \\
\text { loudspeakers, } \\
\text { satellite phones (for } \\
\text { communication to } \\
\text { outer islands) }\end{array}$ \\
\hline
\end{tabular}


Table 6: Role of media in disaster response and preparedness in Micronesia

\begin{tabular}{|c|c|c|c|c|c|}
\hline Country & $\begin{array}{l}\text { Relevant } \\
\text { legislation }\end{array}$ & $\begin{array}{l}\text { Main institutions } \\
\& \text { organisations }\end{array}$ & $\begin{array}{l}\text { Role of broadcast } \\
\text { media }\end{array}$ & Role of telecom & $\begin{array}{l}\text { Primary media } \\
\text { platforms used }\end{array}$ \\
\hline FSM & $\begin{array}{l}\text { Disaster } \\
\text { Preparedness Plan } \\
\text { review currently } \\
\text { being approved. }\end{array}$ & $\begin{array}{l}\text { Department of Public } \\
\text { Safety, FSMTC, Public } \\
\text { Utilities Corporation, } \\
\text { Public Transport } \\
\text { Agency, local } \\
\text { government, Red } \\
\text { Cross, International } \\
\text { Organisation for } \\
\text { Migration (IOM), } \\
\text { Salvation Army, and } \\
\text { private businesses, } \\
\text { National Weather } \\
\text { Service Office. }\end{array}$ & $\begin{array}{l}\text { Local radio stations are } \\
\text { included in the Disaster } \\
\text { Preparedness plan; but } \\
\text { lack of awareness of } \\
\text { this among } \\
\text { stakeholders. Currently } \\
\text { no formal emergency } \\
\text { broadcasting plans. }\end{array}$ & $\begin{array}{l}\text { Currently no formal } \\
\text { plans, but indications } \\
\text { that ICT use in } \\
\text { disaster response is } \\
\text { on the agenda }\end{array}$ & $\begin{array}{l}\text { Police } \\
\text { announcements } \\
\text { using loud hailers \& } \\
\text { PA systems, warning } \\
\text { sirens (in Pohnpei } \\
\text { only) } \\
\text { HF radios }\end{array}$ \\
\hline Kiribati & $\begin{array}{l}\text { National Disaster Act } \\
1993 \text { (was never } \\
\text { implemented). } \\
\text { National Disaster } \\
\text { Management Plan } \\
\text { endorsed in } 2012 .\end{array}$ & $\begin{array}{l}\text { Disaster Risk } \\
\text { Management Office } \\
\text { (DRM), National } \\
\text { Disaster } \\
\text { Management } \\
\text { Committee (NDMC), } \\
\text { Office of the } \\
\text { President, Kiribati } \\
\text { Meteorological } \\
\text { Service (within the } \\
\text { Office of the } \\
\text { President) }\end{array}$ & $\begin{array}{l}\text { Currently no formal } \\
\text { agreements are in } \\
\text { place; informal plans } \\
\text { are for the NDMC to } \\
\text { make all } \\
\text { announcements via } \\
\text { Radio Kiribati }\end{array}$ & $\begin{array}{l}\text { An agreement is } \\
\text { being developed } \\
\text { with Telecom. }\end{array}$ & $\begin{array}{l}\text { Radio Kiribati, police } \\
\text { cars \& loud speakers, } \\
\text { police VHF radios. } \\
\text { Currently no mass- } \\
\text { SMS systems. }\end{array}$ \\
\hline $\begin{array}{l}\text { Marshall } \\
\text { Islands }\end{array}$ & $\begin{array}{l}\text { National Disaster } \\
\text { Management Plan } \\
\text { (1997), official } \\
\text { current plan is not } \\
\text { publically available. }\end{array}$ & $\begin{array}{l}\text { Chief Secretary's } \\
\text { Office, Disaster } \\
\text { Management } \\
\text { Committee, } \\
\text { Atmospheric } \\
\text { Technology Services } \\
\text { Company ATSC (US } \\
\text { Military administered } \\
\text { on Kwajalein Atoll) }\end{array}$ & $\begin{array}{l}\text { Currently no formal } \\
\text { emergency } \\
\text { broadcasting plans; } \\
\text { informal plans are } \\
\text { vague but involve } \\
\text { announcements via } \\
\text { V7AB (radio) }\end{array}$ & $\begin{array}{l}\text { No formal } \\
\text { agreements; telecom } \\
\text { industry undergoing } \\
\text { change. See } \\
\text { http://www.worldba } \\
\text { nk.org/en/news/pres } \\
\text { s- } \\
\text { release/2013/03/19/ } \\
\text { world-bank-marshall- } \\
\text { islands-launch-new- } \\
\text { strategy-to- } \\
\text { strengthen- } \\
\text { partnership }\end{array}$ & $\begin{array}{l}\text { Internet (between } \\
\text { disaster responders) } \\
\text { HF radios (especially } \\
\text { to outer islands) } \\
\text { Mass SMS systems } \\
\text { not used due to legal } \\
\text { barriers. }\end{array}$ \\
\hline Nauru & $\begin{array}{l}\text { Disaster Risk } \\
\text { Management Act } \\
2008\end{array}$ & $\begin{array}{l}\text { National Disaster Risk } \\
\text { Management Office } \\
\text { (NDRMO), Emergency } \\
\text { Operations Centre, } \\
\text { Police Commissioner, } \\
\text { President }\end{array}$ & $\begin{array}{l}\text { The Disaster Risk } \\
\text { Management Act states } \\
\text { that TV and Radio will } \\
\text { be used for emergency } \\
\text { broadcasting but there } \\
\text { are currently no formal } \\
\text { emergency } \\
\text { broadcasting plans }\end{array}$ & $\begin{array}{l}\text { No formal } \\
\text { agreements; ongoing } \\
\text { discussions }\end{array}$ & $\begin{array}{l}\text { Police and Digicel } \\
\text { have satellite } \\
\text { phones. NDRMO is } \\
\text { considering other } \\
\text { warning options } \\
\text { (sirens or PA system) } \\
\text { Digicel can } \\
\text { disseminate SMS } \\
\text { warnings }\end{array}$ \\
\hline Palau & $\begin{array}{l}\text { National Disaster } \\
\text { Risk Management } \\
\text { Framework (2010) }\end{array}$ & $\begin{array}{l}\text { National Emergency } \\
\text { Management Office, } \\
\text { Red Cross, Police, } \\
\text { National Weather } \\
\text { Service }\end{array}$ & $\begin{array}{l}\text { Formal plans describe } \\
\text { an expectation of } \\
\text { compliance by } \\
\text { broadcasters to follow } \\
\text { NEOC direction. Media } \\
\text { staff must liaise with } \\
\text { the NEOC for updates }\end{array}$ & $\begin{array}{l}\text { No formal agreement } \\
\text { with telecoms. See } \\
\text { also: } \\
\text { http://www.sidsnet. } \\
\text { org/msi_5/docs/nars } \\
\text { /Pacific/Palau-MSI- } \\
\text { NAR2010.pdf }\end{array}$ & $\begin{array}{l}\text { Radio, house-to- } \\
\text { house visits in some } \\
\text { areas. }\end{array}$ \\
\hline
\end{tabular}

As Tables 4, 5, and 6 illustrate, some countries have highly developed and comprehensive plans integrating a range of communication infrastructures and platforms. For example, Fiji and 
Samoa have some of the most comprehensive activities. Fiji, which has a national team that coordinates the response to and information dissemination on the impacts of climate change and disaster preparedness, has a disaster communication plan that includes the use of: telephone, internet, warning sirens, short wave equipment, human resources and key individuals, cars with speakers, word of mouth and NGOs, to inform the public. They also embrace traditional knowledge and warning systems (i.e. observations of natural phenomena). Radio, TV, newspapers and telephone facilities, both landline and mobile, combine to cover all areas. During the 2011 floods, radio broadcasters and others used social network sites to access and disseminate information. In some countries, such as Samoa, Papua New Guinea and Tonga, emergency broadcasters are experimenting with sending out SMS messages to mobile phone owners; however, there remain a few difficulties given the limited number of messages that can be sent at one time (200 in Tonga). There were also reports in Papua New Guinea that early warnings were sometimes confused with spam messages and people failed to take any action when receiving SMS warnings.

\section{Conclusion: Locating disaster communication in local communicative ecologies}

Locating disaster management plans within the local communicative ecology does not privilege high-tech over low-tech or vice versa. For example, Samoa has one of the strongest disaster preparedness policies and coordinating bodies in the region, and its disaster plans interweave older communication practices with new approaches and technologies. The early warning system includes a network of sirens in town areas and a refinement of an SMS system, together with networks of village bells, where successive villages ring their bells to warn the next village, who passes the warning on by ringing their bells. In addition to technical solutions, Samoans utilise traditional knowledge of signs of changing weather patterns (Lefale 2009). In many cases villages go through a separate additional process of identifying the risks and developing plans which supplement the national disaster plans and preparations.

Importantly, face-to-face communication remains the most effective warning system and has been acknowledged and incorporated into disaster planning. Often police are the primary communicators and they are often provided satellite phones and radios so they can access the most up-to-date information. For example, in Kiribati the police drive around all of the islands (including outer islands) to inform people about impending emergencies, and in Niue police make a point of meeting with the village councils who, in turn, go around the village to inform people of the alert and advise them to listen to the radio. They also check to make sure people 
have hot water and an emergency kit, and remind them to close their shutters. In the Solomon Islands the police circulate warnings. In other places church bells or conch shells are used. While radio and television are the primary emergency systems in Palau, in the past the governor has also phoned households via landlines and sent people to relay the message to every household. A number of countries continue experimenting with ways to combine face-to-face meetings with mediated forms of awareness information strategies.

An area often neglected in disaster management and climate change communication is language. The use of highly technical terms without translating them into local languages can cause confusion. Information fatigue was observed in some countries like Kiribati and Palau and at least some of this can be attributed to the challenges of translating issues of climate change and disaster planning into locally relevant stories.

Geography remains a key challenge for technicians and others involved in the design and implementation of successful emergency broadcast systems. The vast majority of island nations in the region are geographically dispersed and separated by water or dense forest and vegetation. For example, the government in the Federated States of Micronesia recently purchased a siren warning that is activated by a text message (SMS). Currently the system is only operational in Pohnpei, but they envision that this system will eventually be quite useful for the atoll islands where the siren will be heard across the community; in the past vast distances have hindered effective early warning systems.

In countries such as the Cook Islands, radio and satellite phones are key technologies for reaching the populations in the outer islands. For example, every island has a satellite phone to be used in emergencies and telecommunications companies prepare their staff with High Frequency radios and satellite phones. However, radio alone continues to have shortcomings. In the Cook Islands the radio station that reaches the outer islands transmits on a limited basis and does not broadcast 24/7. Similar coverage gaps can be observed in Palau, the Marshall Islands and the Solomon Islands.

It is important to integrate mobile phones and other ICTs into disaster plans and policies across the Pacific in order to remain relevant in the dynamic and shifting communication environments. To be effective, however, these technologies need to be understood in local contexts. Communicative ecologies provides a useful conceptual framework for this, and, as this paper demonstrates, can help to identify important nuances in affordability, access, trustworthiness, generational and gendered differences, geography, and the influences of cultural and meaning structures and local knowledge in preparing and responding to disasters. 


\section{Acknowledgements}

This paper draws from the 'PACMAS: State of the Media and Communication Report'. We therefore wish to acknowledge ABC International Development, who funded the study, and our co-authors, Verena Thomas and Joys Eggins. We thank Vipul Khosla, Research Manager ABC ID, who commented on a draft of this paper.

\section{References}

Andersen, B. 2013. 'Tricks, Lies, and Mobile Phones: "Phone Friend" Stories in Papua New Guinea' Culture, Theory and Critique 54:3, 318-334

Bengtsson, L; Lu, X; Thorson, A; Garfield, R; Von Schreeb, J. 2011. Improved response to disasters and outbreaks by tracking population movements with mobile phone network data: a post-earthquake geospatial study in Haiti. PLoS medicine, 8(8), e1001083.

Cave, D. 2012. Digital Islands; How the Pacific's ICT Revolution is transforming the region. Accessed January 23, 2014. Available at: http://www.lowyinstitute.org/files/cave_digital_islands_web.pdf.

Donner, J. 2010. 'Framing M4D: The Utility of Continuity and the Dual Heritage of" Mobiles and Development"' The Electronic Journal on Information Systems in Developing Countries Vol. 44 (3), pp. 1-16

Donner, J. 2008. Research Approaches to Mobile Use in the Developing World: A Review of the Literature. The Information Society 24(3), 140-159. See: http://www.tandfonline.com/doi/abs/10.1080/01972240802019970\#.VI6eXHtvDXs

Duffield, Lee; Watson, Amanda H.A.; Hayes, Mark. 2008. "Media and Communication Capacities in the Pacific region" ejournalist Vol 8. (1) p 20-34.

Farbotko, C; Lazrus, H. 2011. The first climate refugees? Contesting global narratives of climate change in Tuvalu. Global Environmental Change, 22(2), pp.382-390.

Handman, C. 2013. 'Text Messaging in Tok Pisin: Etymologies and Orthographies in Cosmopolitan Papua New Guinea' Culture, Theory and Critique 54:3, 265-284

Heinzelman, J; Waters. C. 2010. Crowdsourcing crisis information in disaster-affected Haiti. US Institute of Peace.

Horst, H. A. 2013. 'The Infrastructures of Mobile Media: Towards a Future Research Agenda' in Mobile Media and Communication 1(1). 147-52.

Horst, H. A; Taylor, E. B. 2014. 'The role of mobile phones in the mediation of border crossings: A study of Haiti and the Dominican Republic'. The Australian Journal of Anthropology, 25: $155^{-170 .}$

Horst, H; Miller, D. 2006. The Cell Phone: An Anthropology of Communication. Oxford: Berg.

Intermedia Europe. 2012. "Citizens Access to Information in Papua New Guinea”, ABC International Development. Available at: http://www.abcinternationaldevelopment.net.au/wp-content/uploads/2012/o9/ABC-PNGReport.pdf. 
Jensen, R. 2007. The digital provide: Information (technology), market performance, and welfare in the South Indian fisheries sector. The quarterly journal of economics, 879-924

Lefale, P.F. 2009. Ua 'afa le Aso Stormy weather today: traditional ecological knowledge of weather and climate. The Samoa experience. Climatic Change, 100(2), pp.317-335. Available at: http://www.springerlink.com/index/10.1007/s10584-009-9722-z.

Ling, R; Horst, H.A. 2011. 'Mobile communication in the global south' New Media \& Society 13 363-374

Lipset, D. 2013. 'Mobail: Moral Ambivalence and the Domestication of Mobile Telephones in Peri-Urban Papua New Guinea'. Culture, Theory and Critique 54:3, 335-354

Mas, I; Morawczynski, O. 2009. 'Designing mobile money services lessons from MPESA.' Innovations 4.2, 77-91.

Muliaumaseali'I, M. 2014. "\#didntfeelathing: Mobile phones and tsunami warnings in Samoa”. Accessed from: https://sites.google.com/site/mobilisingmediainthepacific/research-fromthe-field/mobilephonesinsamoa

Paton, K; Fairbaine-Dunlop, P. 2010. "Listening to local voices: Tuvaluans respond to climate change" in Local Environment: The International Journal of Justice and Sustainability Vol 15 (7) pp 687-698.

Pertierra, R; Ugarte, E.F; Pingol, A; Hernandez, J; Lexis Dacanay, N. 2002. Texting selves: Cellphones and Philippine modernity. Manila, Philippines: De La Salle University Press.

Reading, A. 2009. 'Mobile witnessing: Ethics and the camera phone in the "War on Terror". Globalizations 6.1 : 61-76.

Rika, N. 2013. "Climate Change is a justice issue for Pacific people'. Pacific Islands News Association. Available at: http://www.pina.com.fj/?p=pacnews\&m =read\&o=812058780527b13b72dcec48e18doc

Roche, S; Propeck-Zimmermann, E; Mericskay, B. 2013. 'GeoWeb and crisis management: issues and perspectives of volunteered geographic information.' GeoJournal 78:1, 21-40.

Sey, A. 2011. 'We use it different, different': Making sense of trends in mobile phone use in Ghana' New Media \& Society 13 375-390

Slater, Don. 2013. New Media, Development and Globalization: Making Connections in the Global South. John Wiley \& Sons.

de Souza e Silva, A; Sutko, D.M; Salis, F.A; de Souza e Silva, C. 2011. 'Mobile phone appropriation in the favelas of Rio de Janeiro, Brazil' New Media \& Society;13 411-426

Tacchi, Jo. (2014) 'Being Meaningfully Mobile: mobile phones and development' In Servaes, J. (Ed.) Technological determinism and Communication for Sustainable Social Change. Lexington Books.

Tacchi, Jo; Kitner, Kathi. R; Crawford, Kate. 2012. Meaningful Mobility: Gender, development and mobile phones. Feminist Media Studies, 12(4), 528-537.

Tacchi, Jo; Horst, Heather; Papoutsaki, Evangelia; Thomas, Verena; Eggins, Joys. 2013. "PACMAS: State of the Media and Communication Report", Melbourne: PACMAS/ABC International Development. Available at: http://www.pacmas.org/profile/pacmas-state-ofmedia-and-communication-report-2013

Tenhunen, Sirpa. 2008. Mobile technology in the village: ICTs, culture, and social logistics in India. The Journal of the Royal Anthropological Institute, 14(3), 515-534. 
Wallis, C. 2013. Technomobility in China: Young Migrant Women and Mobile Phones. NYU Press.

Wallis, C. 2011. 'Mobile phones without guarantees: The promises of technology and the contingencies of culture'. New Media \& Society 13. 471-485

Watson, A. 2011. The mobile phone: the new communication drum of Papua New Guinea. PhD thesis, Queensland University of Technology Available at:

http://eprints.qut.edu.au/view/person/Watson,_Amanda.html

\footnotetext{
${ }^{1}$ The Pacific Media Assistance Scheme (PACMAS) is an Australian Aid funded regional media program to support better governance in the Pacific through the development of a diverse, independent and professional media, promoting informed and meaningful public discourse region-wide. The program is managed by the Australian Broadcasting Corporation ( $A B C$ ) and is based in Vanuatu.

${ }^{2}$ Tables are arranged by region (Melanesia, Polynesia and Micronesia) for the sake of clarity and readability.

${ }^{3}$ perceptions of research participants; statistics on use unavailable.
} 